\title{
Does prenatal exposure to diclofenac sodium affect the total number of cerebellar granule cells in male juvenile and adult rats?
}

\author{
Fatih Ekicia, İlknur Keskin ${ }^{b}$, Hüseyin Aslanc, Züleyha Erişgin ${ }^{\mathrm{d}}$, Berrin Zuhal Altunkaynak ${ }^{\mathrm{d}}$, Alpaslan Gökçimen ${ }^{\mathrm{e}}$, \\ Ersan Odacif, Süleyman Kaplan*d
}

a Department of Physiology, Medical Faculty, Gaziosmanpaşa University, Tokat, Turkey

b Department of Histology and Embryology, Medical Faculty, Selçuk University, Konya, Turkey

c Department of Histology and Embryology, Medical Faculty, Gaziosmanpaşa University, Tokat, Turkey

$d$ Department of Histology and Embryology, Medical Faculty, Ondokuz Mayıs University, Samsun, Turkey

e Department of Histology and Embryology, Medical Faculty, Süleyman Demirel University, Isparta, Turkey

f Department of Histology and Embryology, Medical Faculty, Karadeniz Technical University, Trabzon, Turkey

\begin{tabular}{|c|c|}
\hline ARTICLE INFO & ABSTRACT \\
\hline $\begin{array}{ll}\text { Article History } \\
\text { Received } & 10 / 02 / 2012 \\
\text { Accepted } & 18 / 02 / 2012\end{array}$ & $\begin{array}{l}\text { A developing embryo is exposed to side effects of diclofenac sodium (DS), a commonly } \\
\text { used non-steroidal anti-inflammatory drug, since women may incidentally become preg- } \\
\text { nant while receiving DS therapy. Several adverse effects of DS have been clearly estab- } \\
\text { lished. However, the effects of prenatal exposure to DS on the developing cerebellum }\end{array}$ \\
\hline $\begin{array}{l}\text { * Correspondence to } \\
\text { Suleyman Kaplan } \\
\text { Department of Histology } \\
\text { and Embryology, Ondokuz Mayis } \\
\text { University Medical Faculty, } \\
\text { Samsun, Turkey } \\
\text { e-mail: skaplan@omu.edu.tr }\end{array}$ & $\begin{array}{l}\text { especially are unclear for granular cells. In this study, we investigated the total number } \\
\text { of granule cells in the cerebellum in control and DS-treated groups of male rats using the } \\
\text { optical fractionator technique. DS (Voltaren, } 75 \mathrm{mg} / 3 \mathrm{ml} \text { ) in a dose of } 1 \mathrm{mg} / \mathrm{kg} \text { daily was } \\
\text { intraperitoneally injected in the drug-treated group of pregnant rats beginning from the } \\
5 \text { th day after mating during pregnancy for } 15 \text { days. Serum physiological at } 1 \mathrm{ml} / \mathrm{kg} \text { dose } \\
\text { was injected in the control group of pregnant rats during the same period and the same } \\
\text { way. Male offspring were obtained after delivery, and each group was divided two sub- } \\
\text { groups that were } 4 \text {-weeks-old ( } 4 \mathrm{~W} \text {-old) and } 20 \text {-weeks-old ( } 20 \mathrm{~W} \text {-old). Our results showed } \\
\text { that there was no significant difference not only between the } 4 \mathrm{~W} \text {-old DS-treated rats and }\end{array}$ \\
\hline $\begin{array}{l}\text { Keywords: } \\
\text { Granule Cell } \\
\text { Diclofenac sodium }\end{array}$ & $\begin{array}{l}\text { control group. These results suggest that the development of the granule cells in the male } \\
\text { cerebellum may not be affected during either in the early or late life of an animal follow- } \\
\text { ing administration of DS during the prenatal period. } \\
\text { J. Exp. Clin. Med., 2012; 29:52-57 }\end{array}$ \\
\hline
\end{tabular}

Cerebellum

J. Exp. Clin. Med., 2012; 29:52-57

Male

Optical Fractionator

Rat

(C) 2012 OMU All rights reserved

\section{Introduction}

The use of non-steroidal anti-inflammatory drugs (NSAIDs) can be expected to increase in the years to come, partly because of the increasing age of the population and partly because of possible new and developing indications (Russell, 2001). Diclofenac sodium (sodium-(O-((2, 6-dichlorophenyl)-amino)phenyl)-acetate; DS) is a major NSAID with potent antiinflammatory, analgesic, and antipyretic effects. DS is used for the relief of pain and inflammation in conditions such as rheumatoid arthritis, osteoarthritis, ankylosing spondylitis, acute gout, and following some surgical procedures (Siu et al., 2000; Savaser et al., 2005).

The therapeutic effects of DS are based on the inhibition of cyclooxygenase (COX). DS acts on the COX pathway in the arachidonic acid cascade. COX converts arachidonic acid into prostaglandins, prostacyclin, and thromboxane $(\mathrm{Ku}$ et al., 1985; Beck et al., 2003; Inan et al., 2006). COX also catalyzes the rate-limiting step in the formation of prostaglandins from arachidonic acid and is the pharmacological target of NSAIDs. In the brain, COX-2, the inducible isoform of COX, is selectively expressed in neurons of the cerebral cortex, hippocampus, and amygdala (Andreasson et al., 2001). Similar to the therapeutic effect, the side effects of NSAIDs depend on the isoforms of COX that they preferentially or selectively inhibit. Complications have been described for most nonselective COX inhibitors but have increasingly been reported for selective COX-2 inhibitors (Ostensen and Skomsvoll, 2004).

There is very little information concerning the effects of DS on the development of the central nervous system (CNS) 
(Kudo et al., 2003). Recently, we reported that DS has neurotoxic effects on hippocampus development in rats following administration of DS during the prenatal period (Gokcimen et al., 2007). To our knowledge, the effect of DS on the number of rat cerebellar granule cells has not yet been clearly established. Therefore, in the present study we investigated the effects of DS on the number of granule cells in the rat cerebellum following administration of DS in the prenatal period using unbiased stereological methods.

\section{Material and methods}

Female albino rats were obtained from the Surgical Research Center. The rats, weighing between 150 and $200 \mathrm{~g}$, were mated overnight and maintained in our laboratory under controlled environmental conditions (an air-conditioned room, room temperature $20 \pm 1{ }^{\circ} \mathrm{C}$ and under a $12 \mathrm{~h}$ light/dark cycle). They were fed ad libitum and kept in separate standard plastic cages. Female rats were accepted as pregnant rats when a vaginal plug was found, and divided into drug-treated and control groups after the mating day. A daily dose of $1 \mathrm{mg}$ / $\mathrm{kg}$ of DS (Voltaren, $75 \mathrm{mg} / 3 \mathrm{ml}$ ampule, Novartis, Mefar Ilaç Sanayi A.S., Kartal-İstanbul, Turkey) was intraperitoneally injected in the drug-treated pregnant rat group beginning from the 5th day after mating during pregnancy for 15 days. Serum physiological at $1 \mathrm{ml} / \mathrm{kg}$ dose was intraperitoneally injected in the pregnant control group rats at the same period and the same way. After spontaneous delivery, male offspring were obtained and separated into two groups (drug-treated and the control). They were marked by branding on their body and again by coloring with picric acid, and fed for 4 and 20 weeks.

At the end of the $4^{\text {th }}$ and $20^{\text {th }}$ weeks, the animals were anaesthetized with urethane $(1.25 \mathrm{~g} / \mathrm{kg})$ and perfused through the left cardiac ventricle with $10 \%$ neutral-buffered formalin. After the skull was opened, the head was immersed in $10 \%$ formalin and fixed for 24 hours at $4^{\circ} \mathrm{C}$. Afterwards, the cerebella were dissected out and stored in $10 \%$ formalin for 10 days at $4^{\circ} \mathrm{C}$. After being rinsed in tap water for $12 \mathrm{~h}$, the cerebella were dehydrated in an alcohol series and embedded in paraffin for sectioning. The paraffin sections of the cerebellum were cut into serial sections of $40-\mu \mathrm{m}$ thickness in the coronal plane via a rotary microtome (Leica RM 2135, Leica Instruments, Nussloch, Germany). Sections were obtained using the disposable metal microtome blades (Type N35, Feather Company, Osaka, Japan) with a cutting (knife bevel) angle of about $5^{\circ}$. The sections were mounted on gelatine-formaldehyde mixture coated glass slides and stored for $24 \mathrm{~h}$ at $37^{\circ} \mathrm{C}$ in a thermostatically controlled oven and later stained with cresyl violet $(0.1 \%)$. All experiments described in the present study were conducted according to institutional guidelines. The Animal Experiments and Ethic committee of Suleyman Demirel University approved the protocol, and appropriate measures were taken to minimize pain or discomfort.

\section{Stereological analysis}

\section{Estimation of total number of neurons}

The optical fractionator counting method was used to obtain the total number of neurons. Based on a pilot study, we decided to select every $6^{\text {th }}$ section through a set of consecutive sections from each cerebellum. Choosing the first sec- tion was done randomly within the first 6 sections for each animal and every successive $6^{\text {th }}$ section was collected from the series, which means a $1 / 6$ section-sampling fraction (ssf). When using the optical fractionator method for cell counting, about 15-20 sections from each cerebellum are known to be adequate to estimate the total number of neurons (Gundersen and Jensen, 1987; West et al., 1991; Tunc et al., 2006; Tunc et al., 2007). Therefore, 15-20 sections were obtained for each cerebellum. Section sampling was begun from a random point and (between 1 and 6) alternate sections were collected as reserves. The counting frame size was $155 \mu \mathrm{m}^{2}$, the area sampling fraction (asf) was $155 \mu \mathrm{m}^{2} / 202,500 \mu \mathrm{m}^{2}$, and the thickness sampling fraction (tsf) was $10 \mu \mathrm{m} / 35 \mu \mathrm{m}$ for granule cells. Details of the counting procedure are summarized in Table 1. The granule cells which are the widest profile of the nucleus that comes into focus were counted. The estimated total number of neurons was calculated from the number of counted neurons and the sampling probability (Gundersen, 1986). The total number of neurons was estimated according to the formula given below:

$$
N=\sum Q \cdot \frac{1}{s s f} \cdot \frac{1}{a s f} \cdot \frac{1}{t s f},
$$

where $\sum \mathrm{Q}$ represents the total number of neurons counted in all optically sampled fields of the cerebellum; ssf is the section sampling fraction (1/6); asf is the area sampling fraction $(155 / 202,500)$; and tsf is the thickness sampling fraction (defined by disector height $(10 \mu \mathrm{m})$ divided by the estimated mean section thickness) (West et al., 1991).

\section{Coefficient of variation and coefficient of error}

The precision of the estimations was calculated as described by Gundersen and Jensen for the coefficient of variation (Gundersen and Jensen, 1987) and Schmitz for the coefficient of error (Schmitz, 1998; Schmitz and Hof, 2000). The coefficient of error (CE) of the sampling schedule of the cerebellum was validated from a pilot study as stated before (CE must be $\leq 10 \%$ ). It is also possible to estimate the coefficient of variation $(\mathrm{CV})$ within the cerebellum in each group. This is valuable data to see whether the number of subjects in each group is sufficient.

\begin{tabular}{|c|c|c|c|c|}
\hline \multicolumn{5}{|c|}{$\begin{array}{l}\text { Table 1: The mean values of coefficie } \\
\text { coefficient of variation }(\mathrm{CV}) \text { of } \\
\text { of total granule cell number in } \\
\text { of } 4 \mathrm{~W} \text {-old and } 20 \mathrm{~W} \text {-old groups } \\
\text { disector particle and sampled } \\
\text { section thickness for each group } \\
\text { Control group } \\
(\mathrm{n}=10)\end{array}$} \\
\hline \multirow[b]{2}{*}{$\begin{array}{l}\text { Disector particle } \\
\text { number }\end{array}$} & $4 \mathrm{~W}$-old & 20W-old & 4W-old & 20W-old \\
\hline & 1192 & 1302 & 1255 & 1308 \\
\hline $\begin{array}{l}\text { Section } \\
\text { thickness }(\mu \mathrm{m})\end{array}$ & 36.1 & 32.8 & 38.0 & 30.7 \\
\hline $\begin{array}{l}\text { Number of } \\
\text { sampled sections }\end{array}$ & 18.0 & 22.6 & 20.0 & 22.0 \\
\hline $\mathbf{C E}$ & 0.03 & 0.03 & 0.03 & 0.03 \\
\hline $\mathrm{CV}$ & 0.09 & 0.07 & 0.09 & 0.07 \\
\hline
\end{tabular}

(CE); Coefficient of error, (CV); Coefficient of variation 
In Table 1, the mean coefficient of variation for each group and the mean coefficient of error for stereological estimation of the number of neurons and other stereological parameters were given.

\section{Stereological equipment}

Stereological analyses were performed at a stereology workstation, the Department of Histology and Embryology, Gaziosmanpasa University Medical Faculty (Tokat, Turkey). It consisted of a modified light microscope [a 100 $\times$ Leica HCX Plan Apo objective; numerical aperture (NA) $=1.35]$ and a motorized specimen stage for automatic sampling (Ludl Electronics; Hawthorne, NY, USA), electronic microcator (Heidenhain, Traunreut, Germany), CCD color video camera (HV-C20AMP; Hitachi, Tokyo, Japan), and stereology software (StereoInvestigator; MBF Biosciences, Williston, VT, USA).

Sampled sections were viewed to identify the nuclei of granule cells using a 100× Leica HCX Plan Apo objective; numerical aperture $(\mathrm{NA})=1.35$. Determining the localization of each granule cell nucleus within the z-axis, the microcator (Heidenhein, Traunreut, Germany) with a resolution of 0.1 $\mu \mathrm{m}$ was used. Oil immersion (Leica Microsystems Wetzlar $\mathrm{GmbH}$, Wetzlar, Germany) with a refractive index $=1.518$ at $23^{\circ} \mathrm{C}$ was used for this measurement. The position of each granule cell nucleus in the disector volume probe and the measurement of the section thickness were determined by focusing in one direction from the upper to the lower section surface. All granule cells were counted; with the widest diameter of the nucleus that came into focus within optical disectors systematically-randomly spaced throughout the delineated regions (Tunc et al., 2006; Tunc et al., 2007). The distance from the upper surface to the lower surface was taken as the section thickness for the site of the disector probe (Gardella et al., 2003; Baryshnikova et al., 2006).

\section{Statistical analysis}

All data were expressed as means \pm standard errors of the mean (SEM) for each group. Comparisons between the various morphometrical measurements of the cerebella of the groups were carried out using the Mann-Whitney U test. When the variances in the population are not equal, the nonparametric test must be used. In this study, the variances were not homogeneous and the compared groups were independent so we used the Mann Whitney U test. In addition, neuron number variables are discrete variables, and each one includes five observations so the expected population's distribution is not normal; normal distribution is another important assumption of parametric tests. If parametric test assumptions are not available, then nonparametric tests should be used for statistics. Mean values were considered to be significantly different when $\mathrm{P}<0.05$.

\section{Results}

\section{Histopathological observations}

No granular cell loss in the 4W-old DS-treated group can be seen as easily corresponding to the control group (Fig. 1).

The histological appearance of the cerebellum of male rats exposed to DS and saline during prenatal life and the in- vestigated postnatal $4 \mathrm{~W}$-old and $20 \mathrm{~W}$-old cerebellum of male rats are shown in Figures 1A, 1B, 1C, and 1D.

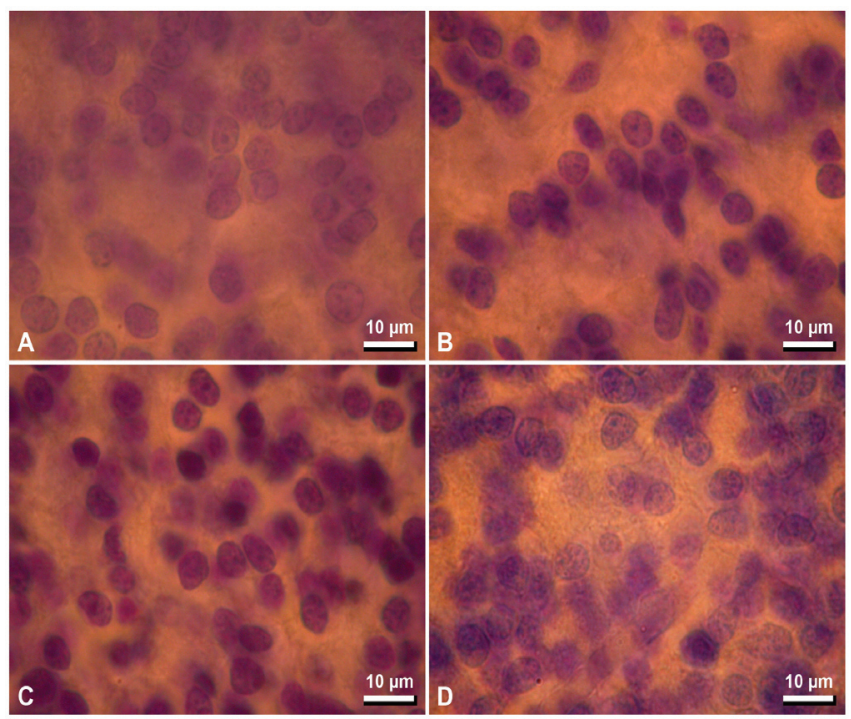

Fig. 1. Micrographs of the rat cerebella belonging to the $4 \mathrm{~W}$-old and $20 \mathrm{~W}$-old control (A and C) and the 4W-old and 20W-old drug-treated (B and D) groups. No changes in the number of granule cells of the cerebellum in the $4 \mathrm{~W}$-old and $20 \mathrm{~W}$-old drug-treated ( $\mathrm{B}$ and $\mathrm{D})$ groups in comparison of their control groups were observed (A and C).

\section{Total number of granule cells in the cerebellum}

Granule cell numbers in the cerebellum were estimated in the two main groups (the drug-treated and the control groups). Each main group was divided into two subgroups: 4W-old and 20W-old. No significant cell loss of the total number of granule cells in $4 \mathrm{~W}$-old and $20 \mathrm{~W}$-old groups was found for the drug-treated group and the control group ( $\mathrm{P}>0.05)$ (Fig. 2).

If the granular cell number in the cerebellum is compared on based on their ages, there were no significant difference between $4 \mathrm{~W}$-old and $20 \mathrm{~W}$-old control groups and also between $4 \mathrm{~W}$-old and 20W-old drug-treated groups (Fig. 3).

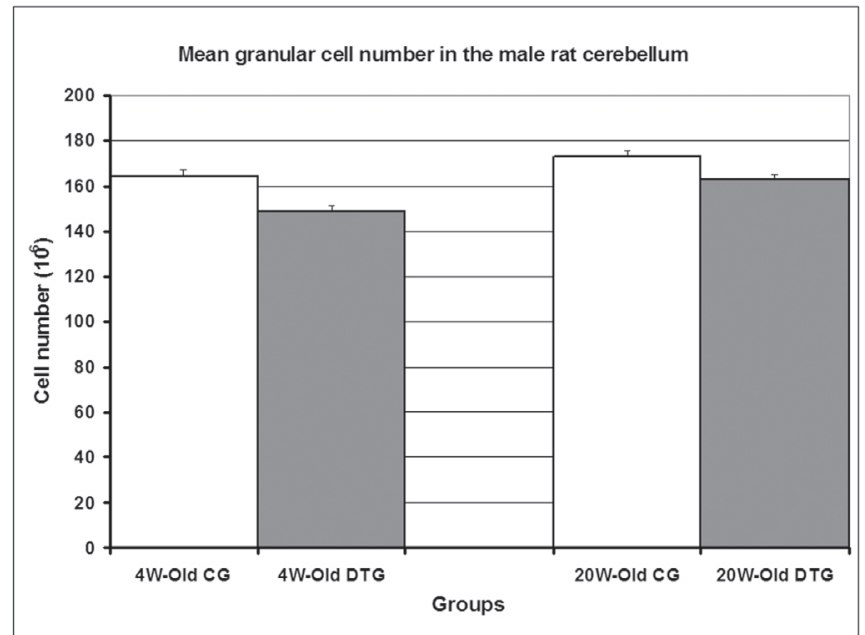

Fig. 2. The mean values of coefficient of error (CE) and coefficient of variation $(\mathrm{CV})$ of stereological analysis of total granule cell number in the male cerebellum of $4 \mathrm{~W}$-old and 20W-old groups are given. The mean disector particle and sampled section numbers and section thickness for each group is also seen. 
That means total cell number in the granular layer of cerebellum of male juvenile and adult rats were not changed by ages.

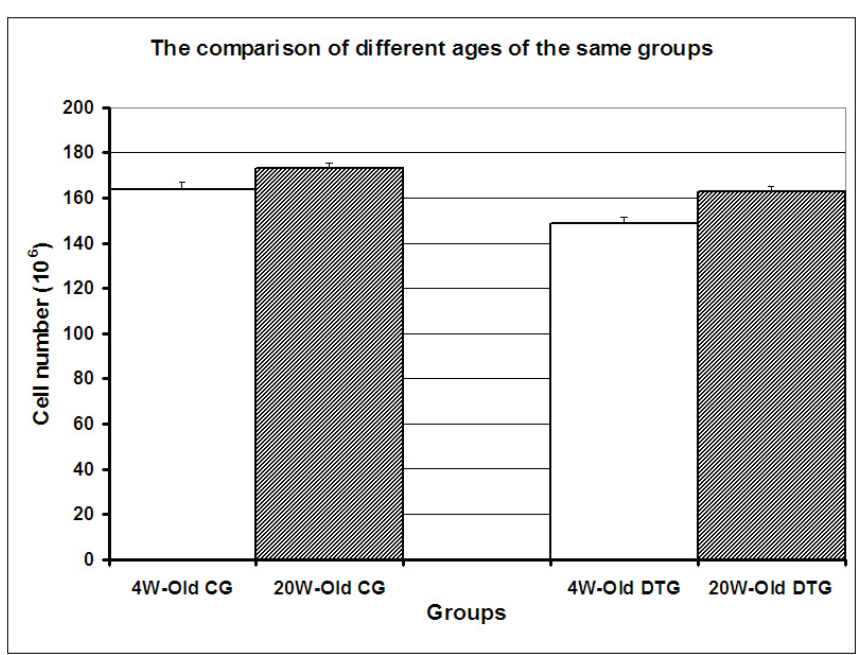

Fig. 3. A comparison of the total number of neurons in the cerebellum between the $4 \mathrm{~W}$-old control and $20 \mathrm{~W}$-old control groups; and also between the $4 \mathrm{~W}$-old drugtreated and $20 \mathrm{~W}$-old drug-treated groups. There were no significant differences between groups, (Mean \pm SEM).

\section{Discussion}

NSAIDs have been used for many years for analgesic, antiinflammatory, and antipyretic purposes. In spite of the wide therapeutic indications of NSAIDs, they have several side effects, such as gastrointestinal damage, nephropathies, skin rashes, and hepatitis (Yakushiji et al., 1992; Russell, 2001; Kudo et al., 2003). Women of reproductive age use NSAIDs as the treatment of choice in primary dysmenorrhea and intrauterine contraceptive device-induced dysmenorrhea. They can be used for effective control of menorrhagia, preterm labor, and polyhydramnios, and to prevent preeclampsia. (Dawood, 1993; Chan et al., 2001).

Women may incidentally become pregnant while receiving NSAID therapy since more than half of all pregnancies are unintended or unplanned (Bitto et al., 1997; Chan et al., 2001). Therefore, the developing embryo is exposed to side effects of DS since there is evidence of good placental transfer of DS in humans (Siu et al., 2000). Recently, a case of severe pulmonary hypertension and transient right-sided hypertrophic cardiomyopathy was described in a neonate, caused by premature closure of the ductus arteriosus after short-term maternal use of DS (Siu and Lee, 2004). Similar to this case, studies of diclofenac-induced teratogenicity were reported during organogenesis (Chan et al., 2001; Siu and Lee, 2004); however, little is known about the effects of NSAIDs on the development of the CNS (Kudo et al., 2003). It has been speculated that DS may affect the development of the CNS and induce malformations, including CNS abnormalities, when given in the first trimester (Chan et al., 2001; Kudo et al., 2003), since DS readily passes the placenta in the first trimester of human pregnancy (Siu et al., 2000). However, researchers have also reported that use of NSAIDs during pregnancy does not seem to increase the risk of adverse birth outcome but is associated with increased risk of miscarriage (Nielsen et al., 2001).
Laboratory studies have shown that DS has teratogenic and postnatal effects in rat embryo models (Carp et al., 1988; Siu et al., 2000; Gokcimen et al., 2007). Experimentally, embryonic development is inhibited by diclofenac when given on gestation day 5. It was shown that diclofenac is toxic at a high concentration of $75 \mu \mathrm{g} / \mathrm{ml}$ to rat blastocysts and causes embryo growth retardation at a concentration of $40 \mu \mathrm{g} /$ ml (Carp et al., 1988; Chan et al., 2001). Researchers have demonstrated that DS exerts direct teratogenic effects on rat embryos. In Chan et al.'s study (2001), rat embryos were cultured in vitro from gestational day 9.5 to 11.5 , which is the critical period of organogenesis in the rat, equivalent to 3-6 weeks after fertilization in human embryos (Chan et al., 2001). The researchers showed that DS demonstrates teratogenic effects in rat embryos at a relatively low concentration $(7.5 \mu \mathrm{g} / \mathrm{ml})$ and observed significant effects on organogenesis when rat embryos were exposed to $\geq 7.5 \mu \mathrm{g} / \mathrm{ml}$ of DS. Studies also showed that the caudal neural tube and hind limb buds were particularly vulnerable to high DS concentrations (7.5 and $15 \mu \mathrm{g} / \mathrm{ml})($ Chan et al., 2001). Recently, we reported a study that investigated DS-induced alterations in the rat hippocampus (Gokcimen et al., 2007). In this study, DS in a dose of $1 \mathrm{mg} / \mathrm{kg}$ daily was intraperitoneally injected in pregnant female rats beginning from the 5th day after mating during pregnancy for 15 days. After delivery, offspring hippocampi were examined at the end of the 4 th and 20 th weeks. A pronounced neuron loss was observed in the drug-treated group. Therefore, we speculated that administration of DS during the prenatal period can interfere with the normal life of the neuron in the rat hippocampus. This may be attributed to the neurotoxicity of DS on the developing hippocampal formation (Gokcimen et al., 2007).

In the present study, we conducted another experimental histological study using unbiased stereological methods upon the granular layer of the rat cerebellum following administration of DS during the prenatal period. Significant results were observed; these are the first reported results using an unbiased stereological technique to investigate DS-induced alterations in the rat cerebellum. First, a significant granule cell loss was not found in the $4 \mathrm{~W}$-old and $20 \mathrm{~W}$-old drug-treated rat cerebellum compared to their control groups. This means that the developing cerebellum especially granular cells may not be susceptible to the neurotoxic effects of DS during the animals' early and late postnatal lives. The tissue concentration of DS is higher than that in maternal plasma, indicating that it may accumulate in fetal tissue with time (Siu et al., 2000), DS may well reach the teratogenic (Chan et al., 2001) as well as toxic level (Ragbetli et al., 2007) in the rat cerebellum. Our previous results showed that the Purkinje cells in the offspring of diclofenac sodium-treated rats were significantly decreased in comparison of the cells of the control animals. In the postnatal life it is well known that very active cellular proliferation and migration take place in the external granular layer (EGL) in the rat cerebellum after the birth. EGL is eliminated at the postnatal life (Sotelo, 2004).

The exact teratogenic mechanism of DS is still being investigated (Montenegro and Palomino, 1990). Some studies postulated that cellular death with NSAIDs (such as aspirininduced malformations) is secondary to disturbed blood supply, which is a consequence of transient vasoconstriction due to the inhibition of synthesis of vasodilator prostaglandins (Klein et al., 1981; Chan et al., 2001). Therefore, the terato- 
genic effects of DS may be similar to those of aspirin because these NSAIDs have similar mechanisms of pharmacological action (Chan et al., 2001). In addition, the teratogenic effects of DS are likely associated with the ability of the phenylacetic acid derivative to compete with arachidonic acid for binding to COX, resulting in decreased prostaglandin formation (Small, 1989; Vane, 1996; Liu et al., 2005). Researchers have also suggested that DS treatment may induce the peripheral or central release of an opioid-like substance (Papworth et al., 1997; Liu et al., 2005). Researchers have sought to better understand the action mechanisms of DS, in the hope that our results may be clearly discussed (Liu et al., 2005).

Our previous results suggest that the Purkinje cells of a developing cerebellum are affected by administration of DS during the prenatal period (Ragbetli et al., 2007). On the other hand in the present study we failed to find similar results for granular cells of the cerebellum. This discrepancy would be explained by the formation time of two type cells, since most of Purkinje cells are formed in the early and late embryonic life (Altman, 1972a), but granular cells is formed in the late embryonic and early postnatal life of animals (Altman, 1972b). That means while prenatal DS exposure decreased the number of Purkinje cells in the cerebellum, but it does not affect the number of granular cells at the same period. We failed to compare our findings with a wide variety of studies since no experimental study in the literature used a stereological method to investigate the effects of DS on the number of granular cells in the rat cerebellum was found.

Second, with animals' age, there is no significant changing in the number of granule cells with age i.e. no difference of cerebellar granular cell number between $4 \mathrm{~W}$ old and $20 \mathrm{~W}$-old rat. This biological comment was true for both the control and drug-treated groups.

In conclusion, our results show that the cerebellar granular layer of the male rat is very dynamic and prenatal exposure of saline and DS does not affect the granular cell number. The cell number also does not change with age. It should be kept in mind that to answer real reason of unchanged granular cell number in the male rat is required further investigations at different developmental periods and different dosages of pre or postnatal DS administration.

\section{REFERENCES}

Altman, J., 1972. Postnatal development of the cerebellar cortex in the rat. I. The external germinal layer and the transitional molecular layer. J. Comp. Neurol. 145, 353-397.

Altman, J., 1972. Postnatal development of the cerebellar cortex in the rat. II. Phases in the maturation of Purkinje cells and of the molecular layer. J. Comp. Neurol. 145, 399-463.

Andreasson, K.I., Savonenko, A., Vidensky, S., Goellner, J.J., Zhang, Y., Shaffer, A., Kaufmann, W.E., Worley, P.F., Isakson, P., Markowska, A. L., 2001. Age-dependent cognitive deficits and neuronal apoptosis in cyclooxygenase-2 transgenic mice. J. Neurosci. 21, 8198-8209.

Baryshnikova, L.M., Von Bohlen Und Halbach, O., Kaplan, S., Von Bartheld, C.S., 2006. Two distinct events, section compression and loss of particles ("lost caps"), contribute to z-axis distortion and bias in optical disector counting. Microsc. Res. Tech. 69, 738-756.

Beck, A., Krischak, G., Sorg, T., Augat, P., Farker, K., Merkel, U., Kinzl, L., Claes, L., 2003. Influence of diclofenac (group of nonsteroidal antiinflammatory drugs) on fracture healing. Arch. Orthop. Trauma Surg. 123, 327-332.

Bitto, A., Gray, R.H., Simpson, J.L., Queenan, J.T., Kambic, R.T., Perez, A., Mena, P., Barbato, M., Li, C., Jennings, V., 1997. Adverse outcomes of planned and unplanned pregnancies among users of natural family planning: a prospective study. Am. J. Public Health. 87, 338-343.

Carp, H.J., Fein, A., Nebel, L., 1988. Effect of diclofenac on implantation and embryonic development in the rat. Eur. J. Obstet. Gynecol. Reprod. Biol. 28, 273-277.

Chan, L.Y., Chiu, P.Y., Siu, S.S., Lau, T.K., 2001. A study of diclofenac-induced teratogenicity during organogenesis using a whole rat embryo culture model. Hum. Reprod. 16, 2390-2393.

Dawood, M.Y., 1993. Nonsteroidal antiinflammatory drugs and reproduction. Am. J. Obstet. Gynecol. 169, 1255-1265.

Gardella, D., Hatton, W.J., Rind, H.B., Rosen, G.D., Von Bartheld, C.S., 2003. Differential tissue shrinkage and compression in the z-axis: Implications for optical disector counting in vibratome,- plastic- and cryosections. J. Neurosci. Methods. 124, 45-59.

Gokcimen, A., Ragbetli, M.C., Bas, O., Tunc, A.T., Aslan, H., Yazici, A.C., Kaplan, S., 2007. Effect of prenatal exposure to an anti-inflammatory drug on neuron number in cornu ammonis and dentate gyrus of the rat hippocampus: a stereological study. Brain Res. 1127, 185-192.

Gundersen, H. J., 1986. Stereology of arbitrary particles. A review of unbiased number and size estimators and the presentation of some new ones, in memory of William R. Thompson. J. Microsc. 143, 3-45.

Gundersen, H.J., Jensen, E.B., 1987. The efficiency of systematic sampling in stereology and its prediction. J. Microsc. 147, $229-263$.

Inan, A., Koca, C., Sen, M., 2006. Effects of diclofenac sodium on bursting pressures of anastomoses and hydroxyproline contents of perianastomotic tissues in a laboratory study. Int. J. Surg. 4, 222-227.

Klein, K. L., Scott, W.J., Wilson, J.G., 1981. Aspirin-induced teratogenesis: a unique pattern of cell death and subsequent polydactyly in the rat. J. Exp. Zool. 216, 107-112.

Ku, E.C., Kothari, H., Lee, W., Kimble, E.F., Liauw, L.H., 1985. Effects of diclofenac sodium on arachidonic acid metabolism. Agents Actions Suppl. 17, 189-193.

Kudo, C., Kori, M., Matsuzaki, K., Yamai, K., Nakajima, A., Shibuya, A., Niwa, H., Kamisaki, Y., Wada, K., 2003. Diclofenac inhibits proliferation and differentiation of neural stem cells. Biochem. Pharmacol. 66, 289-295.

Liu, L.Y., Fei, X.W., Li, Z.M., Zhang, Z.H., Mei, Y.A., 2005. Diclofenac, a nonsteroidal anti-inflammatory drug, activates the transient outward $\mathrm{K}+$ current in rat cerebellar granule cells. Neuropharmacology. 48, 918-926.

Montenegro, M.A., Palomino, H., 1990. Induction of cleft palate in mice by inhibitors of prostaglandin synthesis. J. Craniofac. Genet. Dev. Biol. 10, 83-94.

Nielsen, G.L., Sorensen, H.T., Mellemkjoer, L., Blot, W.J., McLaughlin, J.K., Tage-Jensen, U., Olsen, J.H., 2001. Risk of hospitalization resulting from upper gastrointestinal bleeding among patients taking corticosteroids: a register-based cohort study. Am. J. Med. 111, 541-545.

Ostensen, M.E., Skomsvoll, J.F., 2004. Anti-inflammatory pharmacotherapy during pregnancy. Expert. Opin. Pharmacother. 5, 571-580.

Papworth, J., Colville-Nash, P., Alam, C., Seed, M., Willoughby, D., 1997. The depletion of substance P by diclofenac in the mouse. Eur. J. Pharmacol. 325, R1-R2.

Ragbetli, M.C., Ozyurt, B., Aslan, H., Odaci, E., Gokcimen, A., Sahin, B., Kaplan, S., 2007. Effect of prenatal exposure to diclofenac sodium on Purkinje cell numbers in rat cerebellum: A stereological study. Brain Res. 1174, 130-135. 
Russell, R. I., 2001. Non-steroidal anti-inflammatory drugs and gastrointestinal damage-problems and solutions. Postgrad. Med. J. 77, 82-88.

Savaser, A., Ozkan, Y., Isimer, A., 2005. Preparation and in vitro evaluation of sustained release tablet formulations of diclofenac sodium. Farmaco. 60, 171-177.

Schmitz, C., 1998. Variation of fractionator estimates and its prediction. Anat. Embryol. 198, 371-397.

Schmitz, C. and Hof, P.R., 2000. Recommendations for straightforward and rigorous methods of counting neurons based on a computer simulation approach. J. Chem. Neuroanat. 20, 93-114.

Siu, K. L. and Lee, W. H., 2004. Maternal diclofenac sodium ingestion and severe neonatal pulmonary hypertension. J. Paediatr. Child Health. 40, 152-153.

Siu, S. S., Yeung, J. H., Lau, T. K., 2000. A study on placental transfer of diclofenac in first trimester of human pregnancy. Hum. Reprod. 15, 2423-2425.

Small, R. E., 1989. Diclofenac sodium. Clin. Pharm. 8, 545-558.

Sotelo, C., 2004. Cellular and genetic regulation of the development of the cerebellar system. Prog. Neurobiol. 72, 295-339.

Tunc, A. T., Aslan, H., Turgut, M., Ekici, F., Odaci, E., Kaplan, S., 2007. Inhibitory effect of pinealectomy on the development of cerebellar granule cells in the chick: A stereological study. Brain Res. 1138, 214-220.

Tunc, A. T., Turgut, M., Aslan, H., Sahin, B., Yurtseven, M. E., Kaplan, S., 2006. Neonatal pinealectomy induces Purkinje cell loss in the cerebellum of the chick: a stereological study. Brain Res. 1067, 95-102.

Vane, J. R., 1996. Introduction: Mechanism of action of NSAIDs. Br. J. Rheumatol. 1, 1-3.

West, M. J., Slomianka, L., Gundersen, H. J., 1991. Unbiased stereological estimation of the total number of neurons in thesubdivisions of the rat hippocampus using the optical fractionator. Anat. Rec. 231, 482-497.

Yakushiji, T., Shirasaki, T., Akaike, N., 1992. Non-competitive inhibition of GABAA responses by a new class of quinolones and non-steroidal anti-inflammatories in dissociated frog sensory neurones. Br. J. Pharmacol. 105, 13-18. 